\title{
HOW TO RESIST LINGUISTIC DOMINATION AND PROMOTE KNOWLEDGE DIVERSITY?
}

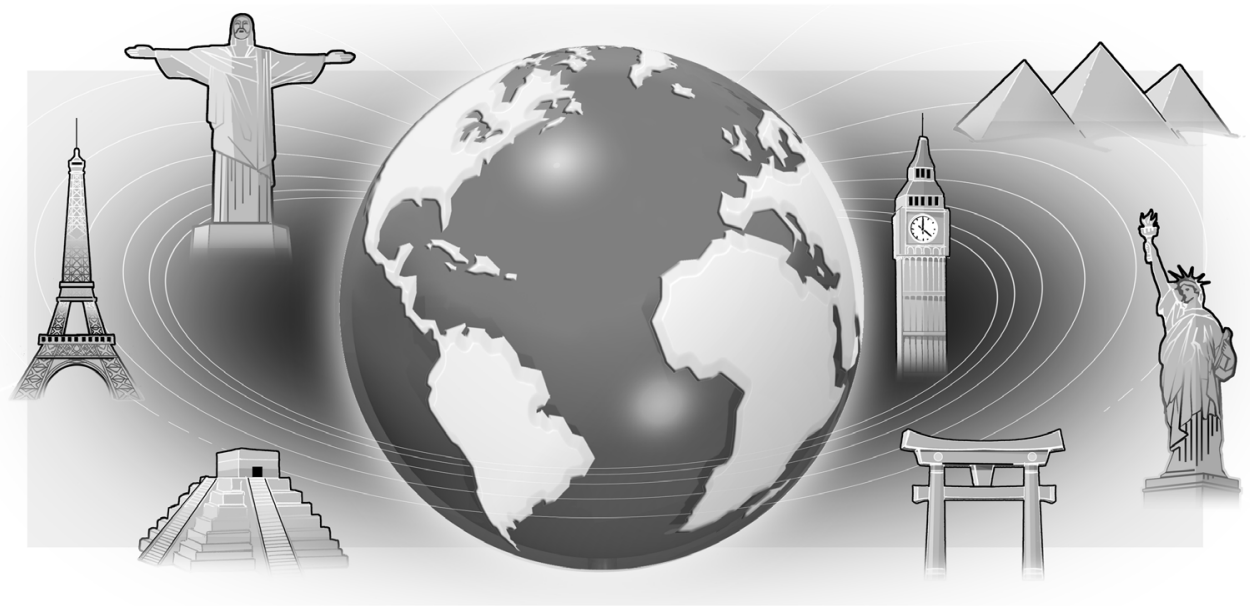

“Imposer sa langue, c'est imposer sa pensée” (Interview with Claude Hagège, L'express, 28/03/2012)

English is a Germanic language introduced in Great Britain around 500 A.D. During four centuries of French domination that followed the Norman Conquest of 1066, this Germanic language was transformed into something completely different: French words were added and most of the complexities of German grammar (gender, case, etc.) were withdrawn, resulting in a language with a huge vocabulary and simple grammar, which could express almost everything. According to Fox (2000), English remained autonomous and open to change (foreign words, new words, and grammatical changes) in contrast, for example, to the French, governed by the purists of the Academie Francaise, which thus led to it becoming the ideal "second language". However, in his posthumous Cours de linguistique générale (1916), Ferdinand de Saussure introduced the foundations for removing the idea that there are stronger or better languages to express certain ideas, trying to show that the allocation of meanings into linguistic signs follows a principle of arbitrariness. This means there is no supremacy of one language over another. But if there is no linguistic supremacy of one language over another, then how can one explain the hegemony of English in the world today?

David Crystal (1997) believes English became the global language in various fields, inclu-

MARIO AQUINO ALVES

Professor at Escola de Administração de Empresas de São Paulo, Fundação Getulio Vargas - São Paulo - SP, Brazil

\section{MARLEI POZZEBON}

Professor at Department of

International Business, HEC Montréal

- Montréal - Québec - Canadá ding the Internet, as an inevitable result of historical circumstances that have led to the spread of the language. And, of course, those circumstances are connected to powers. The powers referred by Crystal (1997) are the political power that England exerted through colonialism from the sixteenth century, the technological power of England as a result of the Industrial Revolution in the eighteenth and nineteenth centuries, the growth of American economic power in the nineteenth century, and the cultural power through spheres of influence, exerted mainly by the U.S. in the twentieth century. In brief, there is no "superior" language, a language is not imposed because 
of its supposed linguistic qualities, but because the State using it is powerful militarily (as in colonization) or economically (as in globalization).

The strongest argument that has been stated in defense of English as an international language is always practical, stressing the advantages of using a widespread language. However, the predominance of English is a form of cultural imperialism, i.e., a symbolic violence that is based on a relationship of limiting communication to force submission, which is characterized by the universalization of particularities associated with a unique historical experience (Bourdieu \& Wacquant, 2000). For the French linguist Hagège (2012). English dominance constitutes a threat to the heritage of humanity and it represents a major risk: to impose a language is to impose a way of thinking. Language is more than communication. Above all, it constitutes a way of seeing the world, an entire culture. Every idiom which disappears represents an inestimable loss, equivalent to a monument or an artwork. The linguist is not fighting against English, but fighting for diversity. Even liberal advocates raise the same concern "[...] and in many countries the all-engulfing advance of English threatens to damage or destroy much local culture. This is sometimes lamented even in England itself, for though the language that now sweeps the world is called English, the culture carried with it is American" (The Economist, 2001).

If the effects of English hegemony in everyday life are tremendous, the same occurs in sciences. To the same extent than 25 languages disappear each year (Crystal, 2000), the plurality of languages in scientific production has decreased in light of the prominence of English in science in recent decades (Hamel, 2007). This becomes a barrier to the participation of other cultures in the international circuit of scientific information (Ibarra-Colado, 2006). This has been the case for management scholar- ship, where the influence of English speaking journals has deepened in the same level as Anglophone business schools. At the institutional level, most countries have adopted patterns of "international scientific production" that generate evaluation rankings that grant higher points to "international" publications, necessarily written in English (Rosa \& Alves, 2011). Internationalization of the higher education sector and the weakening of local and national traditions have accelerated the use of English in non-Anglophone management academic environments, resulting in the majority of work activities being increasingly structured and performed in English, and the emergence of an "international faculty" that is fluent in English and creates knowledge almost exclusively through English (Tietze, 2008). Indeed, their careers are linked to their mastery of English (Tietze, 2008; Rosa \& Alves, 2011). This has been not only a question of molding papers according to international standards, but it is also especially an issue of neglecting other mass spoken languages such as Mandarin, Spanish, Arabic, Hindi, Russian, Portuguese, and French, which altogether comprehend a universe of 3 billion people.

In Le monolinguisme de l'autre (1996), Jacques Derrida reflects on the intertwining relationships between language, social-political context, citizenship and identity. He says that we are doomed to speak only one language, one that is not ours. How could we subvert such a hegemonic trend, which is slowly killing diversity? How could, for instance, non-native English speakers be read? Maybe it should be the case of increasing the number of local native language journals. However, there is no point in assuming that granting researchers the possibility to publish in their native languages will generate better academic work, especially if those scholars reproduce the logic of the "international” (American or European), i.e., translating models and theories that are not related to their own reali- ties. The results - one can observe in local and regional academic venues - are the publication of fragile articles of poor quality. Consequently, even publishing in their native languages may cultivate dependency and mediocrity instead of original thinking. Institutional constraints and inducements have forced many Latin American management researchers to enact strategies of "publishing at any cost", which is evidenced by the steady growth in the number of submissions to journals. On the other hand, these same growth strategies point to little methodological consistency, as seen in the predominance of "pseudo-case studies". Consequently, even publishing in their native languages may cultivate dependency and mediocrity instead of original thinking (see Cooke \& Faria, 2013).

How could we encourage the production of knowledge based less on quantity and international rankings and more on quality? How can we overcome linguistic issues in order to influence global debate? How to overcome the hegemony of English in management scientific production by means of reinforcing alternative publishing, not only in terms of language, but also in terms of formatting?

It is in this context that we aim to discuss the hegemony of English in management scientific production (Alcadipani et al., 2013) and the possibilities of breaking this hegemony by means of reinforcing alternative publishing, not only in terms of language, but also in terms of formatting.

\section{A REFLEXIVE USE OF ENGLISH IN ACADEMIA}

The case is not neglecting the usefulness of English as lingua franca (Hamel, 2007; Kuschner, 2003) but its unreflexive use. Questioning the unreflexive use of English in academic practices in a recent article published by Organization, Chris Steyaert and Maddy Janssens (2012) discuss the paradox of mul- 
tilingual scholarship, inviting scholars to invent new practices regarding language use and language differences. Based on Derrida's (1996) assumption that even when one writes in a colonial/dominant language, he/she should be aware that he/she operates in a multilingual context, they propose three strategies to instigate reflexivity in the use and translation of languages - scandalization, scrutinization and invention.

Scandalization is one of the most effective strategies to public opinion building (Neidhardt, 1993), points out flagrant problems with current policies and practices in academia. Steyaert and Janssens (2012) ask for documenting and protesting against the ongoing naturalization of English and the consequent monolinguism its hegemony imposes. Scandalizing means, for instance, to refuse having conferences or journals that pretend to be "international" and do not reserve spaces and occasions where cultural diversity might be expressed, including diverse languages. This absence should be loudly disapproved, deplored and criticized.

Scandalizing also means to question the massive translation of Anglo-Saxon works into local languages, through the imposition of multinational publishing corporations, without the opposite movement of massive translation of non-English books to English, which results in the decreasing presence of non-English books each year. Non-English books are becoming silent, absent, decreasingly reviewed or referred in "international" journals. In the realm of books, scandalizing also means to denounce the substitution of original editions of local authors - French and Spanish, for instance - by the translated English version. For example, if we consider some of the most important French theorists in humanities and social sciences, like Derrida, Foucault, Bourdieu, Boltansky, Sainsaulieu, Callon or Latour: did they write in their native language or did they become well-known after their work had been writ- ten in English? They first published in their languages. They did not care about rankings and/or JCR. However, it cannot be denied that they were only recognized in the management field after their English "translations" assured their diffusion.

People tend to referee and quote the English version, and not the original version. Why? We must promote diversity by referring and quoting non-Anglophone authors in their native languages. Not quoting enough authors in their native languages means killing diversity.

Scrutinization consists of practices that "inquirw into linguistic negotiations and their effects with regard to power" (Steyaert and Janssens, 2012, p. 132). Here the authors want a more purposive examination of how certain linguistics resources are prioritized in the field and what the consequences are for those choices. One of the biggest signs is the sustained use of references of translations of leading non-Anglophone authors and books instead of the originals. Take the example of French theorists like Callon, Latour, Derrida, Foucault and Bourdieu, to name a few. If we take a look in the reference lists of published articles using those authors, the translated books almost invariably are the ones referenced, not the originals, even if the authors of those articles read or could read the originals. In short, non-Anglophone authors become well-known once their books are translated to English, even if a huge part of the readers could refer to the originals. Could we promote diversity and richness by reading those leading books in their original versions, with all their richness, their nuances, their cultural references, and by including those original references in our research? Another example is the fact that we feel "obliged" (by whom? could we ask) to translate central concepts from its original language to English, losing through that translation the richness, the nuances, the subtleties of its context of production. If we take Brazilian Portuguese to illustrate, think about Roberto Freire's book - "Sem tesão não há solução" - or the well-known expression - o jeitinho brasileiro - or even the legendary and poetic Lusophone word - saudade. No translation is able to capture the original meaning of those words and expressions. Another interesting example brought out by Steyaert and Janssens (2012) is the systematic and often unreflexive translation of raw data and quotes produced in a diversity of languages and contexts to English in the presentation of research results.

Probably, through scrutinization, we can assume that the most dangerous practice in terms of linguistic domination comes from the use of the Journal Impact Factor as an instrument of measurement and assessment of scientific publishing. Created by Eugene Garfield, founder of the Institute for Scientific Information (ISI), the Journal Impact Factor is calculated through the Journal Citation Report (JCR), which belongs to Thomson Reuters. When a journal is evaluated by its Journal Impact Factor, it automatically enters in a system that is immersed in a transnational context of scientific value, which puts its production in direct competition with world production (Rosa and Alves, 2011). The Journal Impact Factor, which is measured from the number of citations of a journal within a certain scientific domain, mostly reflects an English dominated environment. As a consequence, how can non-Anglophone journals compete against English written journals? Putting our non-Anglophone journals on the same basis of indexation of Anglophone journals creates an anticipated tragedy: the extinction of our publications, since they will be so devalued that the flow of non-Anglophone publications will be channeled to English ones because of their greater dominance in the field, contributing to the consolidation of English as a lingua franca.

It is important to note, however, that even in the English speaking scientific community, the overutilization of the Impact Factor to 
assess the quality of scientific production and scientists has been submitted to an emerging criticism. The San Francisco Declaration on Research Assessment (DORA), an initiative of the American Society for Cell Biology (ASCB) and a group of publishers and editors of scientific journals, warns public agencies, policy makers, academic institutions and other publics about "the need to eliminate the use of journal-based metrics, such as Journal Impact Factors, in funding, appointment, and promotion considerations; and, the need to assess research on its own merits rather than on the basis of the journal in which the research is published..." (DORA, 2012)

Finally, the third strategy is invention. Here, creativity and daring are invited to take control. For instance, the mobilization of multiple languages within an English text is seen as enrichment: this means keeping terms, quotes, expressions in the original language, including footnotes with translations or leaving the translation work and interpretation to the reader. In short, instead of reclaiming more diversity and just protesting against Anglophone dominance, Chris Steyaert and Maddy Janssens (2012) recall us that often we are those reproducing such dominance in our everyday research practices. Therefore, the authors clamor for a reinvention of our relationship with language dominance through multilingual scholarship.

\section{INVENTING ALTERNATIVES AND POSSIBILITIES}

In a recent debate - which took place before the $29^{\text {th }}$ EGOS in July 2013 - a group of scholars promoted a passionate discussion around spaces and occasions to increase diversity in terms of language use in academic production. Authors and editors of management journals exchanged interesting thoughts about the issue of English dominance. First, the participants claimed - quite scandalized - the fact that a con- ference taking place in a bilingual city Montreal - and in a Francophone campus - Montreal University - was fully mono-lingual - all activities, panels and sessions in English - even if a huge portion of the attendants were French and Spanish speakers. More than punctual, this absence of non-Anglophone spaces shows how strong this "colonization" process is. It is not simply between North and South, but well rooted inside North and inside South. Several avenues emerged from such a discussion. One of the editors pointed out the alterative of almost real-time translation of texts through the use of cutting-edge functionalities of tools like Google translator. He suggested that discussions with Google are already advanced to provide fast, high quality translation of texts from any language to any language. This alternative would allow authors to write in their native languages and readers to read the translation from a digitalized channel in the language of their choice.

One live alternative within reach of our hands is to encourage and promote the visibility of the already existing multi-language journals. A striking example is Francebased M@n@gement (http://www.management-aims.com/), a journal intended to be open to all other languages and cultures and which already provides the evaluation and publication of texts in other languages such as Spanish, Italian, German or English, offering authors and readers a place to exchange ideas and knowledge that allows a true international vision of management research with all its diversity. Claiming that "a lot of us read many languages but we don't often use these skills”M@n@gement’s policy provides access to articles written in the authors' own language, a direct access to the original version, maintaining the richness and subtlety of the authors' thought. The articles are published as soon as they have been accepted, i.e., there is no delay between acceptance and publication) and this access is free.
A second example of a multi-language management journal is the Brazilian journal RAE-Revista de Administração de Empresas (http://rae.fgv.br/), popularly known as $R A E$, an academic periodical launched in 1961. In order to encourage and disseminate knowledge on management and to promote integration between the Brazilian community and other academic communities around the world, the journal accepts papers in three languages - Portuguese, English and Spanish. Another interesting feature of $R A E$ is free access to all articles and adhesion to a creative commons type of license, which is more flexible and open to knowledge sharing than traditional copyright.

A third example of multi-language journal is the Canadian-based Management International (http://managementinternational.ca/), presented as an independent academic publication that publishes articles in French, English and Spanish from around the world. Its target audiences are scholars and high-level managers who want to keep abreast of the latest knowledge in the field. This openness to different languages contributes to the advancement of knowledge and practice of management at an international level. Since its foundation, Management International has defined itself as a journal that fosters the development of young researchers and encourages debate among scholars from various academic traditions around the world. One of the comments of the editor-in-chief was striking: although the journal encourages cultural diversity and calls for the submission of articles in Spanish, most Spanish-speaking authors insist in submitting their work in English.

These three multi-language outlets represent one of the possible avenues for fostering diversity and resisting English dominance in academic production. Another spot, suggested by one of the participants of this debate, is to encourage so-called "top journals" to open spaces, in the form 
of special issues or other forms, to articles written in different languages. This practice could happen once a year and would promote more visibility and connectivity of non-Anglophone authors.

Finally, some participants recall that even keeping English and the primary language of publications, journal communities and editors could develop a specific identity - around cultural diversity and plurality of thought - as it seems the case of journals like Organization and Scandinavian Journal of Management. Both emphasize openness, creativity and reflexivity as their way to promote diversity and refreshing ideas on an international scale. Another avenue is to promote special issues on topics for which

\section{REFERENCES}

ALCADIPANI, R; DAR, S; GANTMAN, E; YOUSFI, $\mathrm{H}$. Challenging Anglo-Saxon dominance in management and organizational knowledge. Available at: http://rae.fgv.br/sites/rae.fgv.br/ files/file/Call_ChallengingAngloSaxon_final_ comRAE\% $281 \% 29$.pdf. Access on 10.04.2013.

BOURDIEU, P; WACQUANT, L (2000). La nouvelle vulgate planétaire. Le monde diplomatique. Available at: http://www.monde-diplomatique.fr/2000/05/BOURDIEU/13727. Access on 04.10.2013.

COOKE, B; FARIA, A. Desenvolvimento, administração e imperialismo do Atlântico Norte: para Eduardo Ibarra Colado. Cadernos EBAPE. $B R$, v. 11, n. 2, p. 1-15, 2013.

CRYSTAL, D. English as a global language. Cambridge: Cambridge University Press, 1997.

CRYSTAL, D. Language death. Cambridge: Cambridge University Press, 2002.
non-Anglophone scholars have a competitive advantage.

Although all the suggestions and ideas proposed could be beneficial, the question of institutional "incentives" that might lead academics to publish in languages other than English prevail. Scholars around the world are suffering huge pressure to be more "internationally" relevant. However, international means to publish in one language - English - and to address global issues - most of the time those that are grasped by North American and European researchers. The debate we are promoting here asks for a deep questioning for all academic members, authors, editors and particularly direction of management schools.

\section{NOTE OF APPRECIATION}

The authors would like to thank the editors and associate editors Laure Cabantous (M@nagement), Eduardo Diniz, (RAE), Patrick Cohendet (Management International) Robyn Thomas and Chris Steyaert (Organization) for their participation in the "Panel: Editors in Debate- How to resist linguistic domination and promote knowledge diversity?" that we promoted on 2 July 2013 at HEC Montréal as a pre-EGOS Colloquium workshop. Inputs from the audience were also great, and we would like to especially thank Chahrazad Abdallah, Alexandre Barbosa, Luciano Barin-Cruz, Guillaume Blum, Tania Christopoulos, Claudine Gaibrois, Lauro Gonzalez, Fernando Nogueira and Viviane Sergi.
DORA The San Francisco Declaration on Research Assessment (DORA). 2012. Available at: http://am.ascb.org/dora. Access on 04.10.2013.

FOX, J. The triumph of English. Fortune, 12000. Access: http://money.cnn.com/magazines/fortune/fortune_archive/2000/09/18/287720/. Access on 10.04.2013.

HAMEL, R. The dominance of English in the international scientific periodical literature and the future of language use in science. AILA Review, v. 20, p. 53-71, 2007.

HAGÈGE, C. Contre la pensée unique. Paris: Éditions Odile Jacob, 2012.

IBARRA-COLADO, E. Organization studies and epistemic coloniality in Latin America: thinking otherness from the margins. Organization, v. 13, n. 4, p. 463-488, 2006.

KUSHNER, E. English as global language: problems, dangers, opportunities. Diogenes, v. 59, n. 2, p. 17-23, 2003.

L'EXPRESS. Claude Hagège: “Imposer sa langue, c'est imposer sa pensée" ; Par Michel Feltin-Palas (L'Express), publié le 28/03/2012. Available at: http://www.lexpress.fr/culture/ livre/claude-hagege-imposer-sa-langue-c-estimposer-sa-pensee_1098440.html. Access on: 10.04.2013.

NEIDHARDT F. The public as a communication system. Public Understanding of Science, v. 2, n. 4, n. 4, p. 339-350, 1993.

ROSA, A. R; ALVES, M. A. (2011) Pode o conhecimento em gestão e organização falar português? RAE-Revista de Administração de Empresas, v. 51, n. 3 p. 255-264, 2011.

THE ECONOMIST The triumph of English: a world empire by other means. The Economist, 2001. Available at: http://www.economist. com/node/883997. Access on 04.10.2013.

TIETZE, S. The work of management academics: an English language perspective English for Specific Purposes, v. 27, n. 4, p. 371386, 2008. 